\title{
Movie Art Innovation and Its New Aesthetic Dimension in the Media Convergence Era
}

\author{
Haihao Zheng \\ College of Arts \\ Communication University of China \\ Beijing, China \\ College of Digital Art \\ Xi' an University of Posts \& Telecommunications \\ Xi'an, China
}

\begin{abstract}
Media convergence has been started, and will continue to increase. Different art forms in the media ecology are also undergoing a profound and dramatic transformation. The globalization as presented by media convergence has aroused great concern of relevant institutions and scholars engaged in the study of movie art. Through sorting the development context of media convergence, first of all, this paper summarizes and analyzes the development of media convergence, and then from the perspective of movie art, makes the in-depth analysis of the influence on movie art innovation by media convergence, explores the new aesthetic dimension of movie art as generated in the context of media convergence, so as to provide the theoretical basis with certain reference value for the development of movie art in the media convergence era.
\end{abstract}

Keywords $\longrightarrow$ media convergence; movie art; artistic innovation; artistic aesthetics

\section{INTRODUCTION}

Along with the vigorous development of digital media technology, the brand new media communication affects every aspect of human society more directly. From the point of Marxist artistic production theory, the ideology and art production is determined by the corresponding economic base. As the social economic structure and the sum of productive relations, economic base determines the superstructure, including the political and law, social ideology, etc.

With respect to Media Convergence, it was first proposed by Ithiel - Sol · Poole, a scholar of communication. He believes that media convergence is the multi function and the trend of integration symbolized by variety kinds of media. But Andrew Nachison, Director of Media Research Center of American Press Institute, defines media convergence as "the strategic, operational and cultural alliance among the printed, audio, video and interactive digital media organization."

In recent years, China has paid high attention to media industry, and introduced the corresponding instructive policy documents, including the Promotion Plan of Integration of Three Networks issued in August 2015 and Action Plan for Promoting Large Data Development issued in September by

Fund Project: Research project of important theoretical and practical problems in the circle of social science of Shaanxi Province 2015 (No.: 2015Z147).). the State Council. Especially on August 18, 2014, the fourth meeting of the central leading team to comprehensively deepen reform has examined and approved the Guidance on Promoting the Integration Development of Traditional Media and New Media, and described the working concept, implementation path, goals, tasks and overall requirements of media convergence profoundly.

Art has always been the most sensitive to the development of times and the environment changes. Along with the intensifying media convergence, literature \& art theory and art market has presented corresponding changes. Therefore, the research of media convergence's influence on art, literary aesthetics, and technical media is of important theoretical value and practical significance.

\section{DEVElopment TREnd OF Media CONVERGENCE}

\section{A. Convergence of Traditional Media and New Media}

Media convergence is not a single linear change, sometimes it is more like a physical and chemical process. In the process of integration, traditional media face the known or unknown challenges anytime and anywhere, or perhaps meet the baptism in storm generating self fission, and transform into a brand new media with unique characteristics after the storm; or accumulate strength in high temperature and high pressure, and become a new type of media which is vitality after violent fusion and rebirth. No matter the traditional media or new media, or the updated media, under the common effect of different factors such as people, capital and system, they will develop toward the higher dimension with more advantages by media convergence, to provide the different new paths of all media development.

\section{B. Convergence of Media Content and Media Form}

CCITT (Consultative Committee on International Telephone and Telegraph) once defined divided media from the perspective of technology, holding the opinion that media can be divided into: perception media, representation media, presentation media, storage media and transmission media. The media category of media content and media form are highly dialectical unified in the media integration process. 
Media form is the mode of existence of media content, and the structure and organization of the media content. Media content and media form influences and restricts each other. No matter the media content without form or the media form without content, are all the resulted by the reason that media content and media form cannot integrate. At the same time, the relationship between media content and media form is relative. The media form of certain media content will become the media content of another media form. The convergence of media content and media form has realized the new form of media integration.

\section{Convergence of Media Software and Hardware Platform}

In the process of media convergence, the most direct convergence is the deep integration and convergence of various software and hardware platforms. Many devices and sensors are already able to connect with each other, generally using the cable technology or data acquisition and monitoring system, occasionally using radio signals with a certain frequency. Cellular mobile phones were introduced in the 1980s, which can spread voice through different frequency of people's pronunciation, but can't get the data of the machine. In 2001, third generation (3G) cellular communication appeared, and the cellular network can send data, thus made the communication between machine and sensors relatively easy while spreading sound. From a certain perspective, the indepth convergence of hardware and software media is the base to realize connecting everything. According to Report on Trend Prediction of Science, Media and Telecommunications Industry 2015 as issued by Deloitte, "It is expected 1 billion of IoT equipment will be shipped in 2015 , increased by $60 \%$ over 2014 , at that time, there will be 2.8 billion of IoT equipment in the world. Although as of now, relevant statistical data has not been counted up comprehensively, only by the prosperity as presented by CES hold in early 2016, we can see the powerful force of the whole software and hardware market in the whole 2015. These two kinds of communication modes includes: (1) all the equipment that can make voice communication; (2) the equipment only can transmit data, also referred to as the M2M (Machine to Machine).[1]. It can be said that, the mobile terminal represented by the smart phone has laid a solid foundation for the convergence of hardware and software media, and have taken an exploratory step to realize the new scene of connecting everything.

\section{MOVIE ART INNOVATION IN MEDIA CONVERGENCE ERA}

\section{A. Creative Concept of Movie Art Innovation}

Media convergence is the trend of the times, and every aspect of the traditional movie from manufacturing and production will undergo a qualitative change. As for those engaged in movie are creation, there is a fact that they must recognize, namely creative concept is the core competitiveness of movie are in the media convergence era. Relative to the previous one-sided situation of professional movie team, the media convergence era provides the masses and grassroots with the more deceive right of speech in terms of subject selection and aesthetic interest. This transformation from "do what you have seen" to "produce what you want to see" is the concept change based on the interest and selection of Internet users and audiences, that is to say to make the movie art focus more on the audiences' psychological needs. On the other hand, media convergence has provided a very convenient condition for the movie art creators to conduct across art creation. Taking the TV variety show as an example, the program with higher audience ratings in radio, television and network, may get the audiences' detail information through large data investigation and analysis, and the creative team will make a quick decision according to survey data, to determine whether the variety show is suitable for playing. Adjust timely the scenes or plot of popular actors according to the audience feedback. There is no denying the fact that media convergence has also provided the possibility form creators to realize movie performance in such fields as fine arts, drama and music, because the corresponding technical barriers have been dramatically reduced.

\section{B. Spreading of Movie Art Innovation}

As aforesaid, the outstanding feature of media convergence is its integration, characterized in various media terminal, such as television, movies, computers, mobile phones, handheld computers and other media terminals, and the convergence of their screens have been realized through media convergence and network connection. Now, film and television works have achieved multi-screen communication and information content interaction. Especially under the support of convergence of three Networks, television screen, computer screen and mobile phone screen have completed the new transmission pattern of three-screen interaction. Just as Gu Yongqiang of Youku said that the videos in the future will realize full screen play or even without screen. Along with the intensifying media convergence process, the spread of movie art is bound to develop rapidly.

\section{Experience of Movie Art Innovation}

Good art content can only be experienced and perceived by the audiences with good art form. The perfect conjunction of content and form is the base for users' art appreciation and aesthetic experience. The media convergence has provided more abundant choices for the performance of movie art. First of all, strengthen the users' subject initiative. The viewing experience of previous movie art works in terms of script, actors, effect and so on can only be published when the movie is viewed by the audiences in part or in full. In the media convergence ear, users can express directly of their experience in the process of watching movie, or even in the live scene, using such new media forms as MicroBlog and WeChat. The recent bullet screen movie art works is the organic combination of user experience and interaction through integrating the media, and is favored by the young audiences. In addition, the author thinks that with rising and popularization of new media immersion technology with VR (Virtual Reality) as a representative, the users' subjective experience in movie art will be pushed into another more subversive height in the near future. A panoramic style viewing experience, together with the optional game movie with multiple plots involving users and activated by users, will completely refresh the movie art's history of experience. 


\section{Movie Art'S New AEsthetic Dimension IN Media CONVERGENCE ERA}

\section{A. Trans-boundary Beauty of "Movie plus"}

In media convergence era, movie art will open new voyage in the field of art creation."Movie + game", "movie + drama", " movie + music", what needs to be explained specially is that "+ " here is not referred to simple overlay or the mixture based on the form, but the interaction between creation subject and aesthetic subject of movie art and the creation subject and aesthetic subject of different art field such as drama, music, and games in terms of aesthetic experience, aesthetic ideal and aesthetic objective. The creation of a movie works not only includes the movie art creators, but also includes such aspects as drama stage and performing, containing the artistic thoughts of creators from different areas, establishing the unique artistic realm reflecting common essence of art, and different art "rhymes", all these are obtained based on media convergence, and the results of technology integration, capital integration and platform integration. The previous movie art has also tried the integration with different artistic forms such as drama, music and game. But in the era of traditional media, the simple linear superposition doesn't play the effect of $1+1>2$, sometimes even appear to be unnecessary. Only opera movies of Mei Lanfang and the Huangmei Opera movies of Li Hanxiang have certain influence. Then never come to rise again, and even vanished, only appear in the theoretical circle occasionally.

The charm of the media convergence lies in the convenience of communication among creators from different areas; such communication doesn't reach ideological communication. The creators can communicate artistic materials in a timely manner through joining professional network community, including draft script, stage design, character design, scene design, etc., to discuss and solve the problems in various segments while realizing art works. If the former cross-border cooperation needs inspiration, chances as well as creators' knowledge and courage, then in the media convergence era, various cross-border art forms connecting with movie art will become the normal state. And users will also be lucky enough to experience the unique beauty of movie art that connects with different areas.

\section{B. Mixed Beauty of Present and Then}

The time or moment here is a category that breaks through diachronic state and synchronic state. "Present" and "Then" represent the "then" at the time of creating the themes in aesthetic activities and the "Present" at the time of aesthetic receiving subject is appreciating or watching respectively. The "Then" and "Present" are connected closely unprecedentedly in the era of media convergence, even the temporary suspension of time and space happens. Taking Netflix as an example, make a concentrated bet on movie script using big data algorithm through the user test of "Guess You Like". Some others even are trying a new televised production model taking advantage of the technology advantage of media convergence, of which the movie works to be broadcasted are different from traditional movie creation, which completes all the script, and release upon creation. Its model is to actively make use of the technology advantage, platform advantage and resource advantage of media convergence, and determine the developing trend of the plot using final data through in-depth analysis and data mining of the users' or the audiences' behavior large data, which is equivalent to shift the audience's viewing time to an earlier time, and reserve more time for the creator's thinking at "Then", providing creativity, and thus promote the enhancement of the works' quality. Users are willing to pay for the movies that have adopted their views, showing that they are enjoying the pleasure and beauty which mixed "Present" and "Then".

\section{Unified Beauty of Media Ecology and Art Truth}

First of all, the movie art works is the artistic form placed in complex media ecology, which is a form of artistic beauty including the physical state beauty. The media ecology as made up by media convergence has its own unique structure and complexity. In various media ecology, movie art need to stick to their own intrinsic nature, to convey true feelings and express the truth, kindness and beauty. Regardless of the new external technology in media convergence, the foothold of movie art in media convergence era is unifying it with the core nature of movie art.

On the one hand, the art works in media ecology is the product of digitization, and its format, encoding, transmission rate and storage format are all required to meet the requirements of media environment; movie art itself also has the corresponding specification forms in terms of composition, color, and narrative and lens application. On the other hand, the artistic conception, aesthetic purport and the mental and sprit contained in movie art is constantly changing, untouchable, requiring users to appreciate further. Therefore the movie art in media convergence is the unity of media ecology and art truth, rendering people the unified beauty of form and content.

\section{Fantastic Beauty of Virtual and Reality}

Along with the deepening of media convergence degree, and from the previous 2D screen to the 3D landscape simulating human eye, and to wearable visual simulation, the form of movie art to express information and emotion has begun to change profoundly. With the media convergence technology as the foundation, movie art provides the users with a new immersive aesthetic perspective. And users have eventually got rid of the third-party lens in the environment created by media convergence, to feel that imaginary and real dream with their own eyes or other senses, and movie art which has been described as the art of dream creating is finally become the real "dream" of combining truth and the environment. In the movie works, users can experience the fantasy of virtual and reality, or perhaps just as the story described in the Country of Plato: an ethnic group that has lived in the cave for generations, and they have never walked out of the cave, just spending their time by watching the image rejected on the wall inside the cave by the bonfire behind them. This story alerts us that in the image-reading era, we shall be on guard against the rigidified phenomenon as presented by numerous complex visual contents, and it also indicates the 
fatal charming and appealing of movie art toward human in reality and dream, near and far.

\section{CONCLUSION}

The advent of media convergence era is result of common effect of the digital media technology, capital and content resource. As a kind of art form in media convergence era, movie art shall also need to actively deal with the problems faced by it while embracing media convergence with an open and inclusive attitude, namely, how to avoid pure entertainment and commercial trend under the premise of holding fast to the true art; how to properly use the new media technology, to prevent the form deconstruction resulted by excessive application of technology method...These are all the problems need to be studied in-depth by the movie art circle and the industry in future. In short, in media convergence era, opportunities and challenges coexist in the development of movie art.

\section{REFERENCES}

[1] Peng Lan. Four Key Changes under the Direction of Media Convergence. Youth Journalist. 2009（6）.

[2] Xu Ying. Interaction, Integration and Convergence-Three Levels of Media Convergence. Journal of International Communication. 2006 (7).

[3] Xu Hong. Development of Movie Art in Media Convergence Trend. Journalism Lover. 2010（20）.

[4] Hu Zhifeng. Movie Culture and Art in Media Convergence Era. China Television. 2015(1).

[5] Wang Wencheng, Gaoyan. Movie Art in Media Convergence. Chinese Social Sciences Weekly. 2016-1-11.

[6] Huang Jiehui. Artistic Characteristics of Micro Film and its Spreading Rule in Media Convergence Era. Art Science and Technology. 2015(2). 